\title{
Proses Berpikir Siswa Field Dependent dalam Menyelesaikan Masalah Geometri Berdasarkan Tahapan Polya
}

\author{
Agus Hidayat ${ }^{1}$, Cholis Sa'dijah ${ }^{1}$, I Made Sulandra ${ }^{1}$ \\ ${ }^{1}$ Pendidikan Matematika-Universitas Negeri Malang
}

\begin{tabular}{|c|c|}
\hline INFO ARTIKEL & ABSTRAK \\
\hline Riwayat Artikel: & $\begin{array}{l}\text { Abstract: This study aims to describe the thinking process of field dependent students in } \\
\text { solving geometric problems based on the Polya stage. The type of research used was }\end{array}$ \\
\hline Diterima: 28-01-2019 & descriptive qualitative. The study was conducted at SMA 1 Pasuruan using 2 subjects in \\
\hline Disetujui: 24-07-2019 & the cognitive style FD taken from 38 students. The instruments used were in the form of \\
\hline $\begin{array}{l}\text { Kata kunci: } \\
\text { thought process; } \\
\text { field dependent; }\end{array}$ & $\begin{array}{l}\text { cognitive style exams, solving geometrical problems and interview guidelines. The } \\
\text { results of the study show that in processing information, the subject of FD does not } \\
\text { understand the problem as a whole so that in planning the completion of the subject FD } \\
\text { forgets about the concept of the cube. }\end{array}$ \\
\hline $\begin{array}{l}\text { geometry; } \\
\text { polya stage; } \\
\text { proses berpikir; } \\
\text { field dependent; } \\
\text { geometri; } \\
\text { tahapan polya }\end{array}$ & $\begin{array}{l}\text { Abstrak: Penelitian ini bertujuan untuk menggambarkan proses berpikir siswa field } \\
\text { dependent dalam menyelesaikan masalah geometri berdasarkan tahapan Polya. Jenis } \\
\text { penelitian yang digunakan adalah deskriptif kualitatif. Penelitian dilakukan di SMA } \\
\text { Negeri } 1 \text { Pasuruan dengan menggunakan dua subjek bergaya kognitif FD yang diambil } \\
\text { dari } 38 \text { siswa. Instrumen yang digunakan berupa eksamen gaya kognitif, penyelesaian } \\
\text { masalah geometri dan pedoman wawancara. Hasil penelitian memperlihatkan bahwa } \\
\text { dalam memproses informasi, subjek FD tidak memahami masalah secara utuh sehingga } \\
\text { dalam merencanakan penyelesaian subjek FD lupa tentang konsep kubus. }\end{array}$ \\
\hline
\end{tabular}

Alamat Korespondensi:

Agus Hidayat

Pendidikan Matematika

Universitas Negeri Malang

Jalan Semarang 5 Malang

E-mail: hidayatmates@gmail.com

Topik geometri merupakan topik yang penting karena membantu siswa dalam menggambarkan benda-benda kedalam ide-ide geometris (Abdussakir, 2009; Jagom, 2015; Kutluca, 2013; Ma, Lee, Lin, \& Wu, 2015; D. Wu \& Ma, 2006). Siswa belajar geometri untuk mengingat konsep, memahami konteks yang berhubungan dan menerapkan penalaran dalam matematika (Suwito dkk, 2017). Sedangkan menurut (Van de Walle, 2001) pentingnya mempelajari geometri karena pembahasan geometrik dapat membangun keterampilan pemecahan masalah. Siswa harus memiliki kemampuan geometri berupa menggambarkan hubungan spasial geometri, menelaah karakteristik geometris, menerapkan transformasi, menggunakan visualisasi, dan pemodelan geometri untuk memecahkan masalah (NCTM, 2000). Tititk, garis, bidang, dan ruang merupakan ide-ide geometri yang banyak diketahui siswa sehingga siswa mempunyai kesempatan lebih besar dalam memahami topik geometri (Abdussakir, 2012).

Kenyataan yang ada, dari beberapa penelitian menunjukkan penguasaan geometri di sekolah dasar maupun menengah masih rendah (Husnaeni, 2001; Purnomo, 1999). Hasil penelitian (Tristanti, Sa'dijah, \& Gipayana, 2017) menyatakan siswa SD kelas V kurang menguasai soal pemecahan masalah terkait volume kubus dan balok. Menurut (Husnaeni, 2001) siswa SD kelas IV kesulitan memahami karakteristik bangun segitiga dan bukan segitiga. (Amamah, Sa 'dijah, \& Sudirman, 2016) menyatakan bahwa siswa SMP mengalami kesulitan dalam memahami konsep luas dan keliling. Sedangkan Sa'dijah (2008) mengungkapkan bahwa siswa SMP kurang mampu dalam menyelesaikan soal pemecahan masalah pada topik geometri. Di SMA, siswa mengalami kesulitan dalam memahami kedudukan titik, garis, dan bidang pada dimensi tiga (Muniri, 2005). Oleh karena itu, pembelajaran matematika seharusnya lebih fokus untuk membiasakan siswa menggunakan potensi berpikir yang dimiliki. Pembelajaran geometri akan efektif jika dalam prakteknya dilakukan sesuai struktur kemampuan berpikir siswa (Kartono, 2010). Pembelajaran yang disesuaikan dengan kemampuan berpikir siswa mampu meningkatkan kontribusi intelektual siswa dalam proses dan prestasi dalam belajar geometri (Yazdani, 2007). Menurut (Soedjadi, 2000) untuk memahami objek dasar matematika berupa fakta, konsep, operasi, dan prinsip yang konseptual memerlukan proses berpikir. Dengan demikian, pembelajaran matematika selayaknya memberikan penekanan pada proses berpikir siswa. 
Menurut (Santrock, 2004) berpikir adalah tindakan dalam merangkai informasi. Ruggiero (Siswono, 2016) mengartikan berpikir sebagai aktivitas mental untuk memformulasikan suatu masalah, membuat suatu keputusan, atau memenuhi ambisi keingintahuan. Solso (2008) menjelaskan berpikir sebagai proses yang membentuk gambaran mental baru melalui perubahan informasi pada karakter mental berupa pertimbangan, pengabstrakan, penalaran, penggambaran, pembentukan konsep, dan pemecahan masalah. Menurut (Sudarman, 2011) dengan mengetahui proses berpikir siswa, guru dapat memahami letak dan jenis kesulitan siswa. Sehingga guru dapat mengambil tindakan untuk menentukan strategi yang tepat dalam proses pembelajaran. Menurut (Takker \& Subramaniam, 2012) menyatakan bahwa memahami proses berpikir siswa membantu guru dalam memutuskan strategi yang tepat pada pembelajaran, sedangkan (Pehkonen, 2007) mengemukakan bahwa pemecahan masalah telah diterima sebagai cara meningkatkan keterampilan maupun kemahiran berpikir. Selain itu, (NCTM, 2010) menjelaskan bahwa pemecahan masalah memiliki kontribusi penting dalam matematika maupun dalam pendidikan matematika. Berdasarkan beberapa pendapat tersebut dapat disimpulkan pemecahan atau penyelesaian masalah merupakan cara yang tepat dalam pembelajaran untuk membiasakan siswa menggunakan potensi berpikirnya.

Dalam menumbuhkan kemampuan pemecahan masalah kepada siswa, dibutuhkan peran guru untuk mengaitkan soal pemecahan masalah dengan struktur kognitifnya (Wu \& Adams, 2006). Ini memberikan makna bahwa kemampuan pemecahan masalah berkaitan dengan proses berpikir. Oleh karena itu, siswa memiliki cara dan gaya berpikir yang berbeda dalam memecahkan masalah matematika karena kemampuan berpikirnya tidak sama (Ngilawajan, 2013). Menurut (Ardana, 2007) mengemukakan, setiap orang memiliki kemampuan tersendiri dalam memahami dan menginterprestasikan informasi serta kemampuan kognitif yang mengutamakan pengetahuan maupun keterampilan berpikir. Sesuai dengan tinjauan aspek tersebut, perbedaan individu dapat dijelaskan oleh tipe-tipe kognitif yang dikenal dengan istilah gaya kognitif.

Gaya kognitif merupakan cara khas seseorang dalam belajar yang berkaitan dengan penerimaan, pemrosesan, penyimpanan, dan penggunaan informasi untuk merespon suatu masalah (Doyle, 1997). Gaya kognitif sebagai bagian dari perbedaan individu yang menunjukkan karakter seseorang dalam menerima, memikirkan, mengolah, menyimpan, dan menggunakan informasi untuk menanggapi suatu tugas di berbagai situasi (Ahmadzade \& Shojae, 2013). Menurut Hayes dan Allinson (dalam Guisande dkk, 2007) gaya kognitif memengaruhi seseorang dalam mendapatkan, mengatur, menafsirkan dan menggunakan interpretasi informasi untuk mengarahkan suatu tindakan. Beberapa penelitian di bidang psikologi menemukan tipe gaya kognitif yaitu field independent (FI) dan field dependent (FD). Menurut (Kozhevnikov, 2007; Spagnolo \& Di Paola, 2010; Witkin, Moore, Goodenough, \& Cox, 1977) bahwa gaya kognitif FI dalam melihat suatu masalah dipandang secara terpisah. FI memiliki kemampuan analitis kuat, inisiatif, bertanggung jawab, terkontrol, berpikir sendiri, menjauhi orang lain, dan tidak dipengaruhi lingkungan. Sebaliknya gaya kognitif FD menganggap situasi secara keseluruhan, bekerja baik dalam kelompok, dan mementingkan hubungan sosial. Karakteristik dasar gaya kognitif FD dan FI cocok diterapkan pada penelitian yang melibatkan proses berpikir dalam pemecahan masalah matematika.

Masalah adalah suatu situasi yang dihadapi oleh seseorang atau kelompok yang memerlukan suatu pemecahan tetapi mereka tidak memiliki solusinya (Krulik \& Rudnick, 1988). Munandir (2001) mengemukakan bahwa masalah adalah situasi seseorang dalam menyelesaikan persoalan yang belum pernah dikerjakan dan belum memahami penyelesaiannya. Selanjutnya, menurut (Simon \& Newell, 1970) masalah adalah situasi dimana individu ingin melakukan sesuatu tetapi tidak mempunyai cara yang diperlukan untuk memperoleh apa yang ia inginkan. Sementara itu, (Polya, 1973) menyatakan bahwa di dalam matematika terdapat dua macam masalah, yaitu menemukan masalah (problem to find) dan membuktikan masalah (problem to prove). Tujuan dari menemukan masalah adalah untuk menemukan suatu objek tertentu yang tidak diketahui dari masalah. Sedangkan tujuan dari membuktikan masalah adalah untuk menunjukkan kebenaran atau kesalahan suatu pernyataan. Menurut (Kadir, 2010) suatu masalah disebut masalah matematika jika membutuhkan prosedur aritmatika dan aljabar dalam menyelesaikannya. Berdasarkan uraian tersebut, peneliti mengartikan masalah geometri sebagai soal geometri yang perlu dicari penyelesaiannya, tetapi tidak secara langsung ditemukan hasilnya.

Penyelesaian atau pemecahan masalah adalah tindakan individu dalam menggunakan pengetahuan, keterampilan dan pemahamannya untuk memenuhi keadaan yang tidak biasa (Krulik \& Rudnick, 1988). Menurut (Siswono, 2008) penyelesaian atau pemecahan masalah adalah upaya individu untuk merespon (mengatasi) kendala ketika jawaban masih samar. Berdasarkan pendapat tersebut, maka penyelesaian masalah dalam penelitian ini adalah upaya menemukan solusi (jawaban) dari masalah yang diberikan dengan menggunakan pengetahuan (konsep matematika), keterampilan, serta pemahaman yang telah dimiliki. Kemudian (Polya, 1973) menerangkan ada empat tahap dalam pemecahan masalah, yaitu memahami masalah merencanakan penyelesaian, melaksanakan penyelesaian, dan memeriksa kembali.

\section{METODE}

Penelitian ini menggunakan jenis penelitian deskriptif kualitatif. Pelaksanaan penelitian dilakukan di SMA Negeri 1 Pasuruan dengan calon subjek 38 siswa. Calon subjek diberikan eksamen gaya kognitif Group Embedded Figures Test untuk mengelompokkan gaya kognitif FD dan FI. Subjek penelitian yang dipilih adalah dua siswa yang mempunyai gaya kognitif FD. Instrumen utama penelitian adalah peneliti karena berfungsi untuk menghimpun, menilai, menganalisis, dan menafsirkan data 
serta membuat kesimpulan atas temuannya (Sugiyono, 2005), sedangkan instrumen pendukung berupa instrumen GEFT, lembar tes penyelesaian masalah geometri dan pedoman wawancara yang sudah divalidasi.

\section{HASIL}

Pemilihan subjek penelitian diawali dengan pelaksanaan eksamen GEFT yang dikembangkang oleh (Witkin et al., 1977) terhadap 38 siswa kelas XII SMA Negeri 1 Pasuruan. Eksamen GEFT digunakan untuk mengelompokkan siswa berdasarkan gaya kognitif FD atau FI yang terdiri dari tiga bagian. Bagian pertama sebanyak 7 soal sebagai latihan sedangkan bagian kedua dan ketiga sebanyak sembilan soal. Pengelompokkan FD dan FI berpedoman pada skor GEFT bagian dua dan tiga (Rahman, 2010). Siswa yang memperoleh skor tes lebih dari 50\% termasuk siswa FI. Sedangkan siswa yang memperoleh skor tes kurang dari atau sama dengan 50\% termasuk siswa FD. Hasil eksamen GEFT siswa kelas XII SMA Negeri 1 Pasuruan disajikan pada tabel 1.

Tabel 1. Hasil Eksamen GEFT Dari 38 Siswa Kelas XII SMA Negeri 1 Pasuruan

\begin{tabular}{|c|c|c|c|c|c|}
\hline \multirow{2}{*}{ No } & \multirow{2}{*}{ Nama Siswa } & \multirow{2}{*}{ Skor II } & \multirow{2}{*}{ Skor III } & \multicolumn{2}{|c|}{ Tipe Gaya } \\
\hline & & & & II \& III & Kognitif \\
\hline 1 & ALR & 3 & 6 & 9 & FD \\
\hline 2 & AMP & 4 & 7 & 11 & FI \\
\hline 3 & ALK & 5 & 8 & 13 & $\mathrm{FI}$ \\
\hline 4 & $\mathrm{ANH}$ & 0 & 5 & 5 & FD \\
\hline 5 & ANS & 2 & 3 & 5 & FD \\
\hline 6 & $\mathrm{AR}$ & 0 & 5 & 5 & FD \\
\hline 7 & AFA & 6 & 9 & 15 & FI \\
\hline 8 & ARR & 6 & 4 & 10 & FI \\
\hline 9 & $\mathrm{ACS}$ & 5 & 6 & 11 & FI \\
\hline 10 & ARP & 3 & 5 & 8 & FD \\
\hline 11 & BDA & 6 & 8 & 14 & FI \\
\hline 12 & $\mathrm{CR}$ & 2 & 5 & 7 & FD \\
\hline 13 & EFA & 8 & 7 & 15 & FI \\
\hline
\end{tabular}

Menurut tabel 1, diperoleh 21 siswa dengan gaya kognitif FD dan 17 siswa dengan gaya kognitif FI. Subjek yang terpilih adalah ANS dan KMH (baris yang tercetak tebal) dengan mempertimbangkan kemampuan mengemukakan pendapat secara lisan dan tulisan. Setelah kedua subjek mengerjakan TPMG1 dan TPMG2 dilanjutkan dengan wawancara berbasis jawaban TPMG. Soal TPMG1 terlihat pada gambar 1.

Sebuah taman bermain berbentuk persegi dengan ukuran $8 \mathrm{~m}$ x $8 \mathrm{~m}$ dan di keempat pojok taman berturut-turut ada sebuah tiang lampu berwarna merah, biru, kuning, dan hijau dengan tinggi 8m. Bagian paling atas dari tiang lampu saling dihubungkan dengan kabel. Seseorang menaruh tempat makanan burung merpati di pinggir taman, tempat makanan pertama berada tepat di tengah-tengah antara tiang lampu biru dan kuning. Tempat makanan kedua pada jarak $7 \mathrm{~m}$ dari tiang lampu merah dan $1 \mathrm{~m}$ dari tiang lampu hijau. Jika seekor merpati berada pada kabel dengan jarak $2 \mathrm{~m}$ dari tiang lampu merah dan $6 \mathrm{~m}$ dari tiang lampu biru, maka tempat makanan mana yang terdekat dengan burung?

Gambar 1. Soal TPMG1

\section{Paparan Data dan Hasil Wawancara D1 pada tahap Memahami Masalah TPMG1}

Paparan data pada bagian ini merupakan penyajian data yang telah direduksi oleh peneliti mengenai aktivitas subjek FD dalam memahami masalah TPMG1. Kutipan wawancara terhadap subjek FD1 dalam memahami masalah TPMG1 (berinisial D1G1) dengan peneliti (berinisial P) sebagai berikut:

P-5
D1G1-5
P-6
D1G1-6
P-9
D1G1-10
P-14
D1G1-14
D1G1-15

: Berapa kali anda membaca soal tersebut?.

: Saya baca soal itu... tiga sampai empat kali.

: Apakah anda membaca soal tersebut secara keseluruhan atau hanya pada kalimat tertentu saja? .

: Keseluruhan pak.

: Apa inti dari masalah tersebut?.

: (Subjek membaca soal TPMG1) ee..e ini pak, menentukan tempat makanan manakah yang terdekat dengan burung merpati.

: Bagaimanakah cara anda mendeskripsikan kembali permasalahan pada soal dengan bahasa anda sendiri?.

: Dengan membuat menggambar pak.

: Dalam gambar saya, seperti ini (menunjuk Gambar 2), diketahui dulu persegi dengan sisi 8m, empat tiang dengan tinggi $8 \mathrm{~m}$, terus saya kasih lingkaran itu lampunya, yang kotak dua ini tempat makanan (menunjuk kotak berinisial $\mathrm{R}$ dan $\mathrm{Q}$ ), yang kotak ini merpatinya (menunjuk kotak berinisial $\mathrm{P}$ ). 


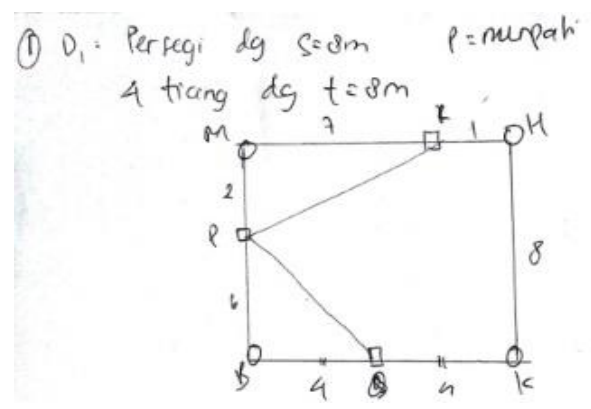

\section{Gambar 2. Bangun persegi yang dibuat oleh subjek D1 dalam memahami TPMG1}

Data yang terlihat pada subjek D1 dalam memahami TPMG1 dari kutipan wawancara diatas adalah subjek D1 membaca soal TPMG1 sebanyak tiga sampai empat kali secara keseluruhan (D1G1- 5, D1G1-6). Kemudian menggambar bangun persegi (gambar 2) dan menjelaskan langkah dalam menggambar bangun tersebut(D1G1-15). Bangun yang digambar tidak sesuai dengan permasalahan Subjek D1 menemukan informasi yang diketahui (D1G1-15), ditanyakan (D1G1-9 dan D1G1-10) dan mendeskripsikan kembali pemahamannya terhadap soal TPMG1(D1G1-14, D1G1-15). Soal TPMG2 disajikan pada gambar 3.

\section{Paparan Data dan Hasil Wawancara D1 pada tahap Memahami Masalah TPMG2}

Sebuah taman bunga berbentuk persegi dengan ukuran $6 \mathrm{~m}$ x $6 \mathrm{~m}$ dan di keempat pojok taman berturut-turut ada sebuah tiang lampu berwarna merah, biru, kuning, dan hijau dengan tinggi $6 \mathrm{~m}$. Bagian paling atas tiang lampu saling dihubungkan dengan kabel. Seseorang menaruh makanan burung merpati di pinggir taman, makanan yang pertama berada di tengah-tengah antara tiang lampu biru dan kuning. Sedangkan makanan yang kedua berada pada jarak $5 \mathrm{~m}$ dari tiang lampu merah dan $1 \mathrm{~m}$ dari tiang lampu hijau. Jika seekor merpati berada di kabel dengan jarak $2 \mathrm{~m}$ dari tiang lampu merah dan $4 \mathrm{~m}$ dari tiang lampu biru, maka makanan mana yang terdekat dengan burung merpati?

\section{Gambar 3. Soal TPMG2}

Sedangkan kutipan wawancara terhadap subjek FD1 dalam memahami masalah TPMG2 (berinisial D1G2) dengan peneliti (berinisial P) sebagai berikut.

P-5 : Berapa kali anda membaca soal tersebut?

D1G2-5 : : Tiga sampai empat kali.

P-6 : Apakah anda membaca soal tersebut secara keseluruhan atau hanya pada kalimat tertentu saja? .

D1G2-6 : Keseluruhan pak.

D1G2-10 : Ya pak (subjek membaca lagi soal TPMG2), ini pak... makanan manakah yang terdekat dengan burung merpati.

P-11 : Apa saja informasi yang perlu diketahui pada soal tersebut?.

D1G2-11 : Ada taman bunga berbentuk persegi dengan ukuran 6 × 6. Ada empat tiang lampu, warna merah biru kuning hijau dengan tinggi $6 \mathrm{~m}$. Terus ada tempat makanan di pinggir taman yang tempat makanan yang pertama ada di tengah-tengah antara lampu biru dan kuning, tempat makanan yang kedua berjarak $5 \mathrm{~m}$ dari lampu merah dan $1 \mathrm{~m}$ dari lampu hijau. Kemudiannnn diketahui seekor merpati berada pada kabel dengan jarak $2 \mathrm{~m}$ dari tiang lampu merah dan $4 \mathrm{~m}$ dari tiang lampu biru.

P-14 : Bagaimanakah cara anda mendeskripsikan kembali permasalahan pada soal dengan bahasa anda sendiri?”

D1G2-14 : Dengan membuat menggambar pak.

D1G2-15 : Dalam gambar saya, seperti ini (menunjuk Gambar 4), diketahui persegi dengan sisi 6m, empat tiang dengan tinggi $6 \mathrm{~m}$, yang saya kasih lingkaran itu berarti lampunya, dan yang kotak dua ini tempat makanan (menunjuk kotak berinisial R dan Q), yang kotak ini merpati (menunjuk kotak berinisial P). 


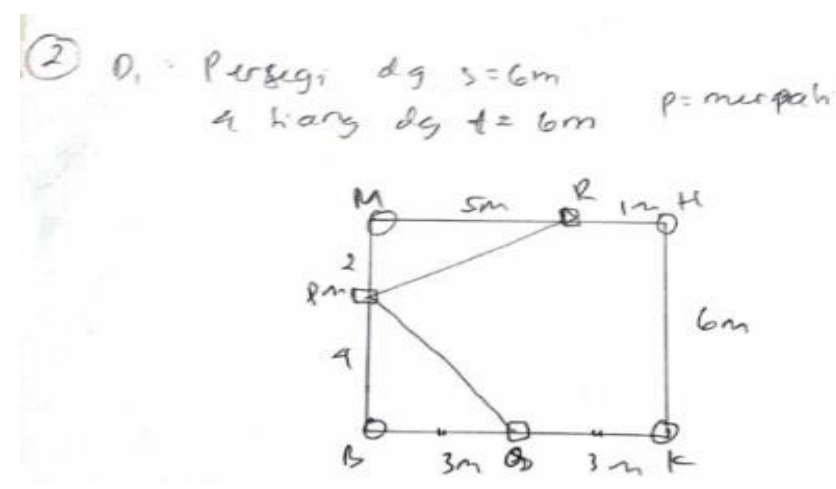

Gambar 4. Bangun persegi yang dibuat oleh subjek D1 dalam memahami TPMG2

Data yang terlihat pada subjek D1 dalam memahami TPMG2 dari kutipan wawancara diatas adalah subjek D1 membaca soal TPMG2 sebanyak tiga sampai empat kali secara keseluruhan (D1G2- 5, D1G2-6). Selanjutnya menggambar bangun dan menjelaskan langkah dalam menggambar bangun tersebut (D1G2-15). Bangun yang digambar tidak sesuai dengan permasalahan. Subjek D1 menemukan informasi yang diketahui (D1G2-11), ditanyakan (D1G2-10) dan mendeskripsikan kembali pemahamannya terhadap soal TPMG2 (D1G2-14, D1G2-15).

Berdasarkan perbandingan data hasil wawancara subjek D1 dalam memahami TPMG1 dan TPMG2, terlihat kedua data merupakan data yang konsisten. Sehingga data yang diperoleh pada wawancara TPMG1 adalah valid. Dari hasil validasi data maka dapat dianalisa aktivitas mental subjek D1 dalam memahami masalah. Yaitu subjek D1 menerima informasi dengan membaca soal sebanyak tiga sampai empat kali disertai menggambar. Subjek D1 mengolah informasi dengan mengaitkan informasi yang diketahui, ditanyakan dengan pengetahuan sebelumnya(konsep persegi, segitiga dan rumus Pythagoras). Subjek D1 menyimpan informasi dengan melakukan pengulangan informasi dalam memahami masalah. Dengan cara menggambar bangun yang terbentuk yang terkait dengan permasalahan. Subjek D1 memanggil kembali informasi yang ditunjukkan oleh penjelasan subjek tentang pemahamannya terhadap permasalahan dengan menggunakan bahasa sendiri.

Paparan Data dan Hasil Wawancara D1 pada tahap Merencanakan Penyelesaian TPMG1 yaitu:

Kutipan wawancara terhadap subjek D1 (inisial D1G1) dengan peneliti (inisial P) dalam merencanakan penyelesaian

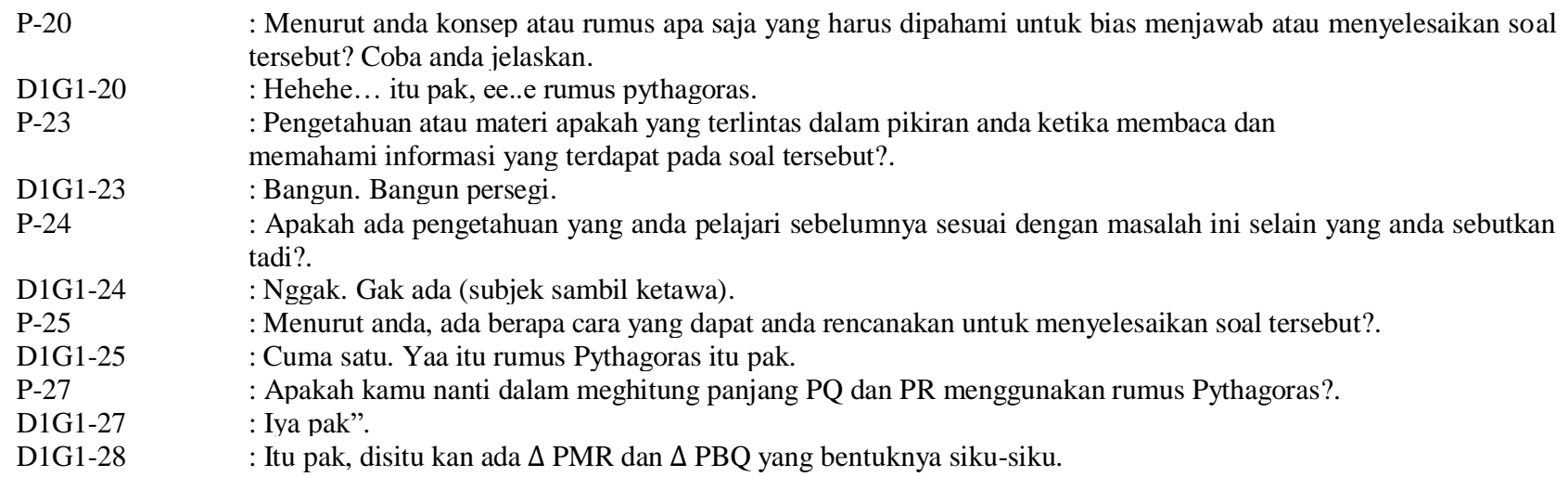

Berdasarkan kutipan wawancara tersebut diperoleh data subjek D1 mengingat konsep segitiga (D1G1-20, D1G1-28) dan konsep persegi (D1G1-23) tetapi tidak mengingat kubus (D1G1-24). Subjek D1 mengingat rumus yang mendukung rencana penyelesaian yaitu rumus Pythagoras (D1G1-25, D1G1-27).

Rencana Subjek D1 untuk menghitung panjang garis PQ dan garis PR dengan menggunakan rumus Pythagoras (D1G1- 27) adalah logis. Rencana Subjek D1 menggunakan $\triangle \mathrm{PMR}$ dan $\triangle \mathrm{PBQ}$ untuk menentukan panjang PR dan PQ dengan rumus Pythagoras (D1G1-28) adalah tidak logis. 


\section{Paparan Data dan Hasil Wawancara D1 pada tahap Merencanakan Penyelesaian TPMG2}

yaitu:

Kutipan wawancara terhadap subjek D1 (inisial D1G2) dengan peneliti (inisial P) dalam merencanakan penyelesaian

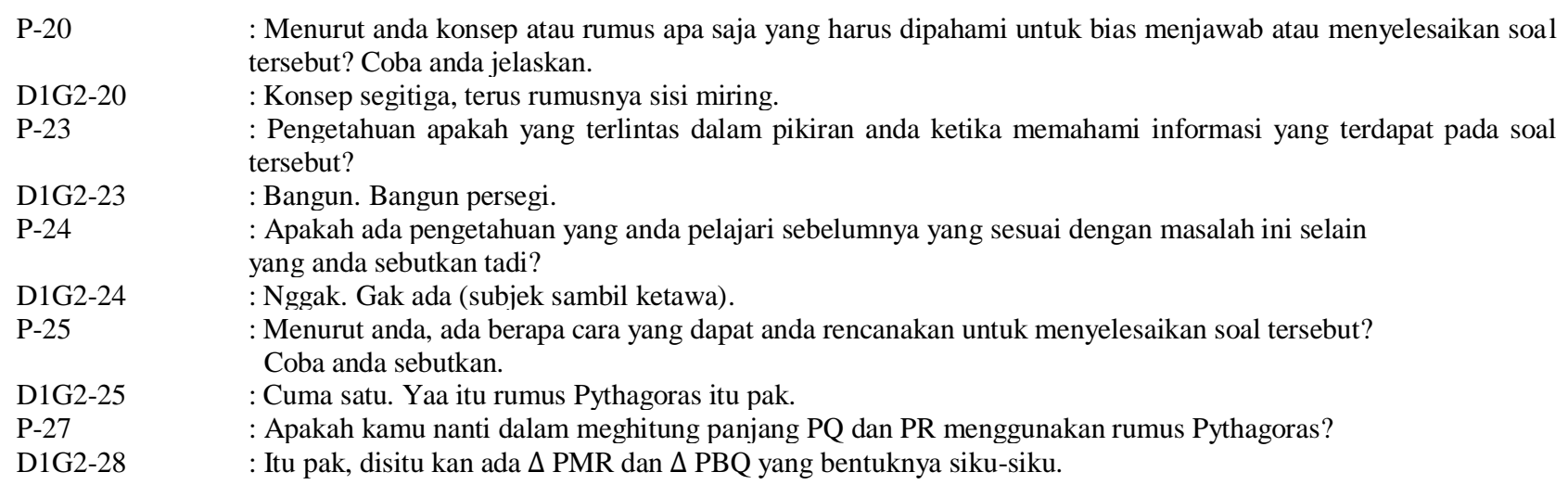

Menurut kutipan wawancara tersebut diperoleh data subjek D1 mengingat konsep segitiga (D1G2-20) dan konsep persegi (D1G1-23) tetapi tidak mengingat kubus (D1G2-24). Subjek D1mengingat rumus yang mendukung rencana penyelesaian yaitu Pythagoras (D1G2-25, D1G2-27). Rencana Subjek D1 untuk menghitung panjang garis PQ dan garis PR dengan menggunakan rumus Pythagoras (D1G2- 27) adalah logis. menggunakan $\triangle \mathrm{PMR}$ dan $\triangle \mathrm{PBQ}$ untuk menentukan panjang PR dan PQ dengan Pythagoras (D1G2-28) adalah tidak logis.

Berdasarkan perbandingan data dari hasil wawancara subjek D1 dalam merencanakan penyelesaian TPMG1 dan TPMG2, terlihat kedua data merupakan data yang konsisten. Sehingga data yang diperoleh pada wawancara TPMG1 adalah valid. Dari hasil validasi data maka dapat dianalisa aktivitas mental subjek D1 pada tahap merencanakan penyelesaian. Yaitu subjek D1 memanggil kembali informasi pemahamannya terhadap permasalahan dengan mengingat konsep segitiga dan rumus Pythagoras. Subjek D1 mengolah informasi pemahamannya terhadap permasalahan TPMG1 dengan pengetahuan yang dikuasai yaitu persegi tetapi tidak mengingat konsep kubus. Subjek D1 menyimpan informasi dengan melakukan pengulangan konsep segitiga siku-siku dan rumus Pythagoras untuk menyusun rencana penyelesaian.

\section{Paparan Data dan Hasil Wawancara D1 pada tahap Melaksanakan Rencana Penyelesaian TPMG1} berikut:

Kutipan wawancara terhadap subjek D1 dengan peneliti dalam melaksanakan rencana penyelesaian TPMG1 sebagai
P-33
D1G1-33
: Bagaimana anda merencanakan penyelesaian dari masalah tersebut?.
P-39
: Yaa dipikirkan pak, setelah membaca soal kemudian ada rencana untuk menggambar dan menghitung.
D1G1-39
: Bagaimana caranya?.
: Begini pak, setelah membaca saya membuat gambar yang terbentuk sesuai pemahaman saya terhadap informasi- informasi yang ada disoal pak (gambar 5). Terus saya mencari jarak dari R ke P dan Q ke P, maka digambar ada garis PR dan garis PQ, dari situ saya melihat dua segitiga siku-siku PMR dan PBQ, pak (subjek menunjuk segitiga yang terbentuk pada gambar 5). Setelah itu saya mengggunakan rumus Pythagoras untuk menghitung jarak dari $\mathrm{R}$ ke $\mathrm{P}$ dan $\mathrm{Q}$ ke $\mathrm{P}$. Setelah ketemu hasilnya saya bandingkan mana yang lebih kecil nilainya. Dari situ maka saya menyimpulkan tempat makanan yang paling dekat dengan burung merpati adalah hasil perhitungan yang nilainya lebih kecil.

Berdasarkan kutipan wawancara tersebut diperoleh data subjek D1 mengingat rencana penyelesaian dan melaksanakan rencana penyelesaiannya sesuai dengan rencana yang dibuat (D1G1-33, D1G1-39, dan gambar 5) dan mengingat rumus Pythagoras (gambar 4.7). Subjek D1tidak logis dalam menggambar bangun (D1G1-39 dan gambar 4.7), tidak logis dalam menghitung panjang garis RP serta garis QP (D1G1-33 dan gambar 4.7). 


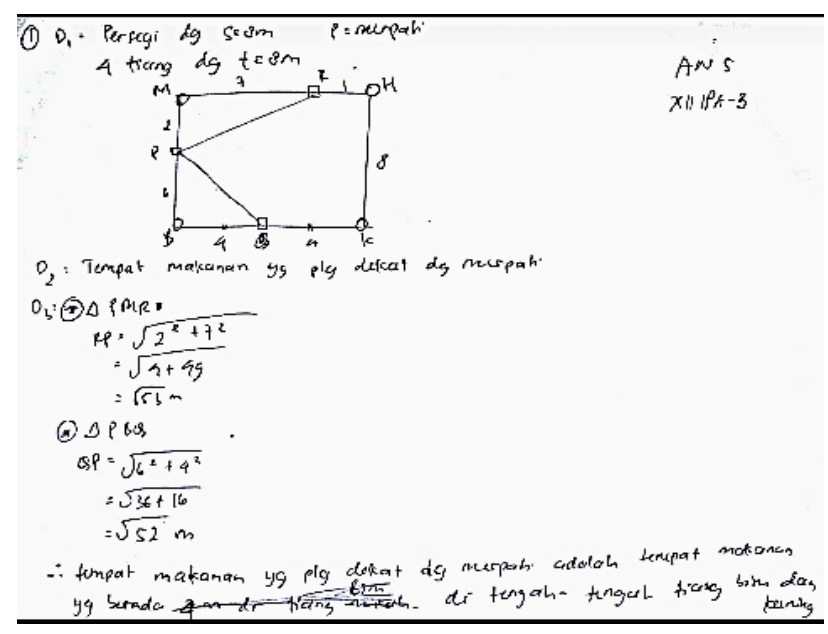

\title{
Gambar 5. Subjek D1 dalam Melaksanaan Rencana Penyelesaian TPMG1
}

Paparan Data dan Hasil Wawancara D1 pada tahap Melaksanakan Rencana Penyelesaian TPMG2 berikut:

Kutipan wawancara terhadap subjek D1 dengan peneliti dalam melaksanakan rencana penyelesaian TPMG2 sebagai
P-33
D1G2-33
P-39
D1G2-39

\begin{abstract}
: Bagaimana cara anda merencanakan penyelesaian dari masalah tersebut?.
: Membaca soal dulu kemudian ada rencana untuk menggambar dan menghitung jarak yang dicari.

: Bagaimana caranya?".

: Caranya saya baca dulu soalnya , terus membuat gambar yang sesuai pemahaman saya terhadap informasi yang ada disoal pak (subjek menunjuk gambar yang dibuat (Gambar 6). Terus saya menghitung jarak dari $\mathrm{R}$ ke $\mathrm{P}$ dan $\mathrm{Q}$ ke P, maka digambar ada garis PR dan garis PQ. Saya lihat segitiga siku-siku yaitu PMR dan PBQ, pak (Gambar 6). Saya mengggunakan rumus Pythagoras untuk menghitung jarak dari R ke P dan Q ke P. Lalu menyimpulkan tempat makanan yang paling dekat dengan burung merpati yaitu hasil perhitungan yang nilainya lebih kecil.
\end{abstract}

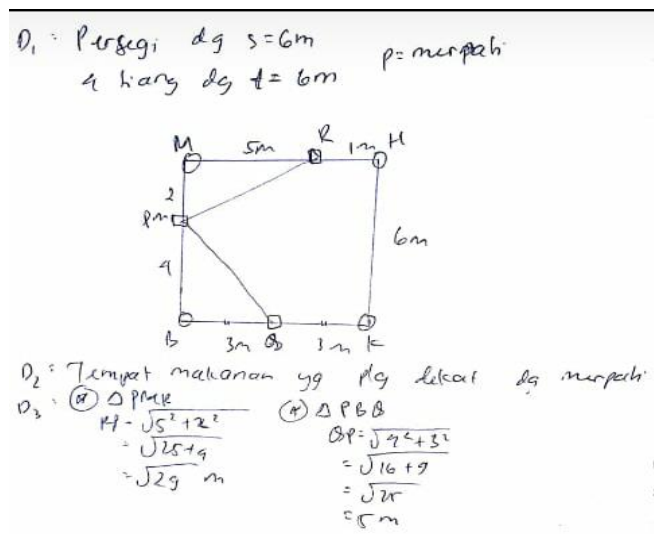

\section{Gambar 6. Subjek D1 dalam Melaksanaan Rencana Penyelesaian TPMG2}

Berdasarkan kutipan wawancara tersebut diperoleh data subjek D1 mengingat rencana penyelesaian dan melaksanakan rencana penyelesaiannya dan mengingat rumus Pythagoras (D1G2-33, D1G2-39, dan gambar 6). Subjek D1 beragumen tidak logis dalam menggambar bangun sesuai informasi yang ada di soal(D1G2-39 dan Gambar 6) dan tidak logis dalam menghitung panjang garis RP dan QP (D1G2-33 dan gambar 6).

Berdasarkan perbandingan data dari hasil wawancara subjek D1 dalam melaksanakan rencana penyelesaian TPMG1 dan TPMG2, terlihat bahwa kedua data merupakan data yang konsisten. Sehingga data yang diperoleh pada wawancara TPMG1 adalah valid. Dari hasil validasi data maka dapat dianalisa aktivitas mental subjek D1. Yaitu subjek D1 memanggil kembali informasi berupa rencana penyelesaian menghitung jarak R ke P dan Q ke P. Dan mengingat rumus Pythagoras yang akan digunakan untuk menyelesaikan masalah. Subjek D1 mengolah informasi dengan mengaitkan rencana penyelesaian, informasi 
dari soal dan pengetahuan yang dikuasai dalam melaksanakan penyelesaian. Subjek D1 tidak berargumen logis dalam membuat bangun dan menentukan jarak R ke P maupun Q ke P. Dalam menyimpan informasi subjek D1 melakukan pengulangan langkahlangkah merencanakan penyelesaian.

\section{Paparan Data dan Hasil Wawancara D1 pada tahap Memeriksa Kembali TPMG1}

Kutipan wawancara terhadap subjek D1 dengan peneliti dalam memeriksa kembali penyelesaian TPMG1 sebagai berikut:

$\begin{array}{ll}\text { P-43 } & \text { : Bagaimana anda memeriksa setiap langkah yang anda lakukan dalam menyelesaikan soal tersebut? } \\ \text { D1G1-43 } & \begin{array}{l}\text { : Itu... melihat gambar, terus sambil mikir logikanya gimana sampai dapat seperti itu, kemudian } \\ \text { memeriksa hitungannya dengan membayangkan apakah hasilnya sesuai dengan hitungan saya. }\end{array} \\ \text { P-44 } & \begin{array}{l}\text { : Apakah anda sudah yakin bahwa jawaban yang anda peroleh tersebut adalah benar? } \\ \text { : Tidak pak, hehehe. Karena saya agak bingung, tempat makanannya itu kalau ditaruh dibawah berarti jadi bangun } \\ \text { ruang. Ah... mungkin diatas, jadi burungnya terbang kesana gitu, jadi bangun datar. }\end{array} \\ \text { P-46 } & \text { : Apakah jawaban anda sudah sesuai dengan inti dari permasalahan pada soal tersebut? } \\ \text { D1G1-46 } & \text { : Kayaknya belum dech. Karena ragu tempat makanannya dimana. }\end{array}$

Berdasarkan kutipan wawancara tersebut diperoleh data S\subjek D1 memeriksa kembali jawabannya dengan cara melihat gambar sambil berpikir secara logis dan memeriksa perhitungannya dengan cara membayangkan (D1G1-43). Subjek D1 tidak yakin dengan hasil pekerjaannya (D1G1-44).

Subjek D1 mengaitkan hasil penyelesaiannya dengan inti dari permasalahan pada soal (D1G1-46).

\section{Paparan Data dan Hasil Wawancara D1 pada tahap Memeriksa Kembali TPMG2} berikut:

Kutipan wawancara terhadap subjek D1 dengan peneliti dalam memeriksa kembali penyelesaian TPMG2 sebagai

$\begin{array}{ll}\text { P-43 } & \text { : Bagaimana anda memeriksa setiap langkah yang anda lakukan dalam menyelesaikan soal tersebut? } \\ \text { D1G2-43 } & \begin{array}{l}\text { : Dilihat gambarnya pak, terus sambil mikir gimana sampai dapat seperti itu, terus memeriksa. } \\ \text { perhitungannya dengan membayangkan apakah hasilnya sesuai dengan hitungan saya. }\end{array} \\ \text { P-44 } & \text { : Apakah anda sudah yakin bahwa jawaban yang anda peroleh tersebut adalah benar? } \\ \text { D1G2-44 } & \text { : Tidak pak. Saya masih bingung dengan posisi makanannya pak, apakah diatas atau dibawah. } \\ \text { P-46 } & \text { : Sepakah jawaban anda sudah sesuai dengan inti dari permasalahan pada soal tersebut? } \\ \text { D1G2-46 } & \end{array}$

Berdasarkan kutipan wawancara tersebut diperoleh data subjek D1 memeriksa kembali jawaban dengan melihat gambar sambil berpikir dan memeriksa perhitungannya dengan dibayangkan(D1G2-43). Subjek D1 tidak yakin dengan hasil pekerjaannya (D1G2-44) setelah memeriksa jawabannya. Subjek D1 mengaitkan hasil penyelesaiannya dengan inti dari permasalahan pada soal (D1G2-46).

Berdasarkan perbandingan data dari hasil wawancara subjek D1 pada tahap memeriksa kembali, terlihat bahwa kedua data merupakan data yang konsisten. Sehingga data yang diperoleh pada wawancara TPMG1 adalah valid. Dari hasil validasi data maka dapat dianalisa aktivitas mental subjek D1 pada tahap memeriksa kembali. Yaitu subjek D1 memanggil kembali informasi dengan mengingat rencana penyelesaian dan melaksanakan rencana penyelesaian. Subjek D1 mengingat inti permasalahan yaitu menentukan tempat makanan yang terdekat dengan burung merpati dan mengingat pengetahuan yang dikuasai (yaitu konsep segitiga dan rumus Pythagoras) untuk melakukan pemeriksaan. Subjek D1 mengolah informasi yaitu mengaitkan kembali inti dari permasalahan dengan hasil penyelesaian yang telah dilakukan. Subjek D1 tidak yakin dengan hasil pekerjaannya setelah melakukan pemeriksaaanjawaban.

Paparan Data dan Hasil Wawancara D2 pada Tahap Memahami Masalah TPMG1

Paparan data pada bagian ini merupakan penyajian data yang telah direduksi oleh peneliti mengenai aktivitas subjek D2 dalam memahami masalah TPMG1. Kutipan wawancara terhadap subjek field dependent kedua dalam memahami masalah TPMG1 (berinisial D2G1) dengan peneliti (berinisial P) sebagai berikut:
P-5
D2G1-5
: Berapa kali anda membaca soal tersebut?
P-6
: Sekitar tiga sampai empat pak.
D2G1-6
: Apakah anda membaca soal tersebut secara keseluruhan atau hanya pada kalimat tertentu saja?
P-11
: Keseluruhan, semuanya pak.
: Apa saja informasi yang perlu diketahui pada soal tersebut? 
D2G1-11 : Sebuah taman bermain yang ukurannya 8 x 8. Terus ada tiang lampu yang berada di pojok-pojok taman yang bermacam- macam.

P-14 : Bagaimanakah cara anda mendeskripsikan kembali permasalahan pada soal dengan bahasa anda sendiri?”.

D2G1-14 : Dengan membuat gambar pak.

P-15 : Bisa dijelaskan.

D2G1-15 : Khan yang pertama digambar tamannya dulu berbentuk $8 \times 8$, terus menempatkan lampunya yang sesuai yang di ujung-ujung taman tersebut. Terus meletakkan makanannya yang sesuai ukurannya ini (menunjuk Gambar 7). Tempat makanan 1 ditengah-tengah antara tiang lampu biru dan kuning. Tempat makanan 2 berada satu meter dari tiang hijau dan tujuh meter dari tiang merah. Dan merpatinya berada pada jarak $2 \mathrm{~m}$ dari tiang merah dan $6 \mathrm{~m}$ dari tiang biru.

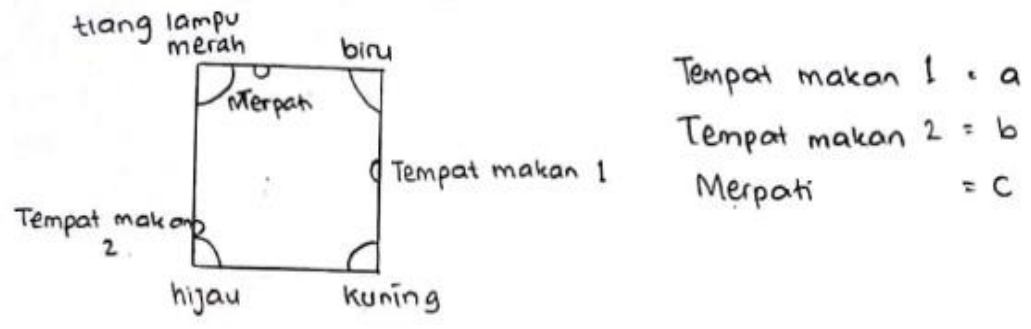

\section{Gambar 7. Gambar bangun persegi yang dibuat oleh subjek D2 dalam memahami soal TPMG1}
$\mathrm{P}-16$
D2G1-16
: Jadi dari soal itu, gambarnya berbentuk persegi.
: Iya persegi.

Data yang terlihat pada subjek D2 dalam memahami TPMG1 dari kutipan wawancara diatas adalah subjek D2 membaca soal TPMG1 sebanyak tiga sampai empat kali secara keseluruhan (D2G1- 5, D2G1-6). Subjek D2 menggambar bangun persegi dan menjelaskan langkahnya (gambar 7 dan D2G2-16, D2G1-15). Bangun yang digambar tidak sesuai dengan permasalahan. Subjek D2 menemukan informasi yang diketahui, ditanyakan dan dapat mendeskripsikan kembali pemahamannya terhadap soal TPMG1 (D2G1-11, D2G1-14, D2G1-15).

\section{Paparan Data dan Hasil Wawancara D2 pada tahap Memahami Masalah TPMG2}

Kutipan wawancara terhadap subjek field dependent kedua dalam memahami masalah TPMG2 (berinisial D2G2) dengan peneliti (berinisial P) sebagai berikut:

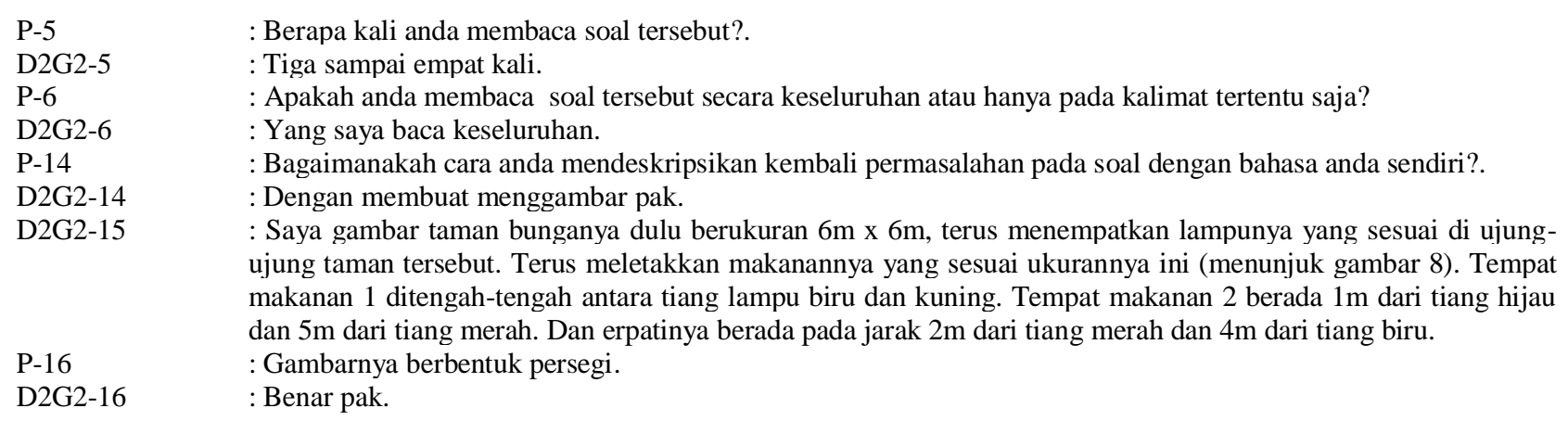

Data yang terlihat pada subjek D2 dalam memahami TPMG2 dari kutipan wawancara diatas adalah subjek D2 membaca soal TPMG2 sebanyak tiga sampai empat kali secara keseluruhan (D2G2- 5, D2G2-6). Subjek D2 menggambar bangun persegi dan menjelaskan langkah dalam menggambar bangun (D2G2-15 dan D2G2-16). Bangun yang digambar tidak sesuai dengan permasalahan.Subjek D2 menemukan informasi yang diketahui, ditanyakan dan mendeskripsikan kembali pemahamannya terhadap soal TPMG2 (D2G2-14, D2G2-15 dan gambar 8)

Berdasarkan perbandingan data dari hasil wawancara subjek D2 dalam memahami masalah TPMG1 dan TPMG2, terlihat bahwa kedua data merupakan data yang konsisten. Sehingga data yang diperoleh pada wawancara TPMG1 adalah valid. Dari hasil validasi data maka dapat dianalisa aktivitas mental subjek D2 dalam memahami masalah. Yaitu subjek D2 menerima informasi dengan membaca soal sebanyak tiga sampai empat kali disertai menggambar. Persepsi subjek terhadap soal yang diterima adalah menggambar bangun untuk mempermudah memahami masalah. Subjek D2 mengolah informasi dengan 
mengaitkan informasi yang diketahui, ditanyakan, dan pengetahuan yang dikuasai berupa konsep persegi, segitiga dan rumus Pythagoras. Subjek D2 menyimpan informasi dengan melakukan pengulangan informasi dalam memahami masalah serta memanggil kembali informasi pemahamannya terhadap permasalahan dengan menggunakan bahasa sendiri.

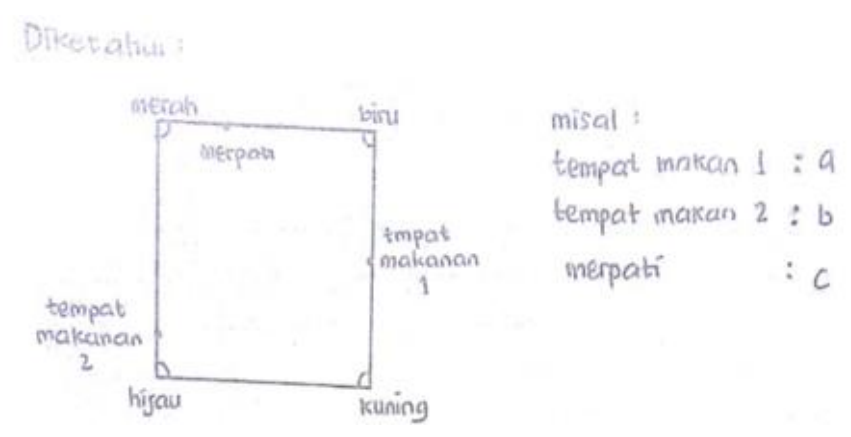

Gambar 8. Gambar bangun persegi yang dibuat oleh subjek D2 dalam memahami TPMG

Paparan Data dan Hasil Wawancara D2 pada tahap Merencanakan Penyelesaian TPMG1

Kutipan wawancara terhadap subjek D2 dengan peneliti dalam merencanakan penyelesaian TPMG1 sebagai berikut:

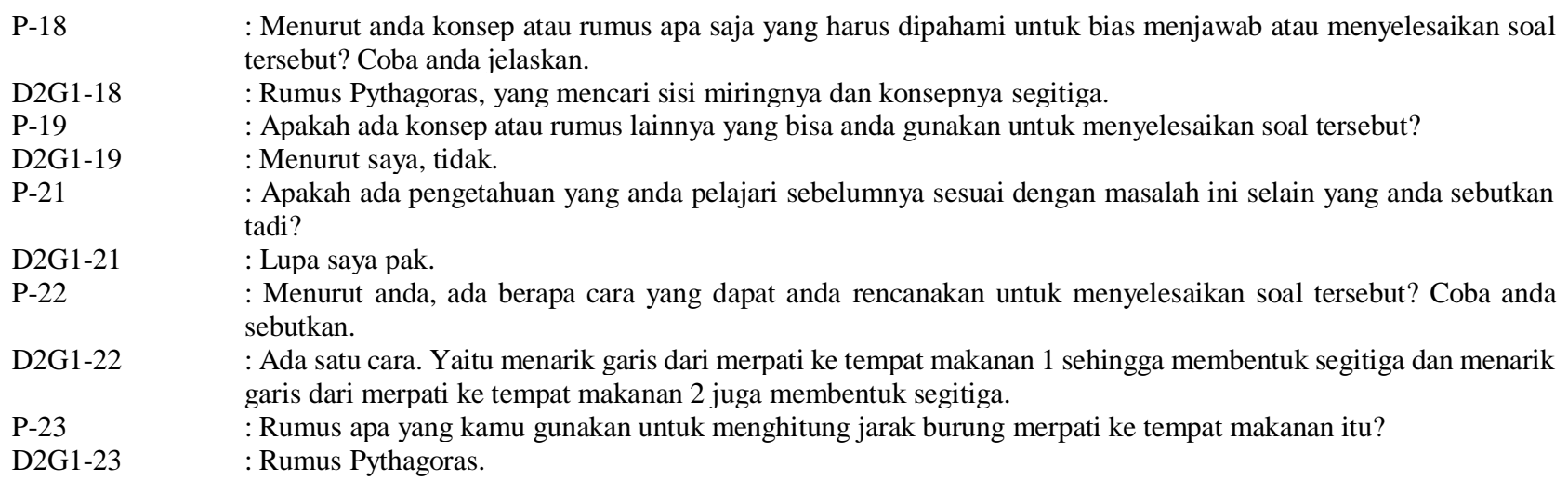

Berdasarkan kutipan wawancara tersebut diperoleh data subjek D2 mengingat konsep segitiga (D2G1-18, D2G1-22) dan konsep persegi tetapi tidak mengingat kubus (D2G1-19 dan D2G1-21). Subjek D2 mengingat rumus yang mendukung rencana penyelesaian yaitu Pythagoras (D2G1-18, D2G1-20 dan D2G1-23), menentukan jarak merpati dengan tempat makanan menggunakan rumus Pythagoras (D2G1- 22) adalah tidak logis.

Paparan Data dan Hasil Wawancara D2 pada tahap Merencanakan Penyelesaian TPMG2

Kutipan wawancara terhadap subjek D2 dengan peneliti dalam merencanakan penyelesaian TPMG2 sebagai berikut:

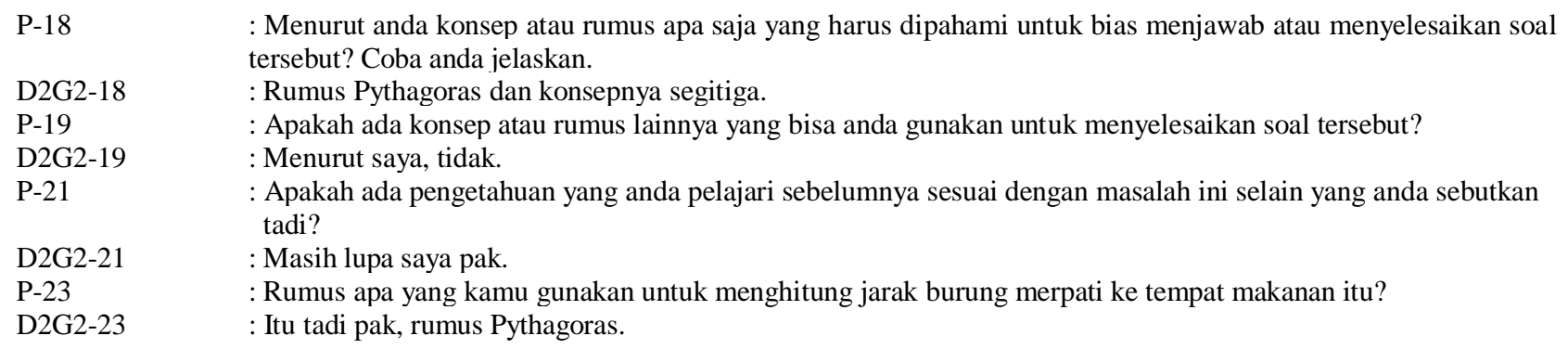


Dari kutipan wawancara tersebut diperoleh data subjek D2 mengingat konsep segitiga (D2G2-18 dan D2G2-24) dan konsep persegi (D2G2-24), tetapi tidak mengingat kubus (D2G2-19 dan D2G2-21). Subjek D2 mengingat rumus yang mendukung rencana penyelesaian yaitu rumus Pythagoras (D2G2-18 dan D2G2-23). Rencana Subjek D2 untuk menentukan jarak burung merpati dengan tempat makanan dengan menggunakan rumus Pythagoras (D2G2- 23) adalah tidak logis.

Berdasarkan perbandingan data dari hasil wawancara subjek D2 dalam merencanakan penyelesaian TPMG1 dan TPMG2, terlihat bahwa kedua merupakan data yang konsisten. Sehingga data yang diperoleh pada wawancara TPMG1 adalah valid. Dari hasil validasi data maka dapat dianalisa aktivitas mental subjek D2 pada tahap merencanakan penyelesaian. Yaitu subjek D2 memanggil kembali informasi pemahamannya terhadap permasalahan dengan mengingat konsep segitiga dan rumus Pythagoras. Subjek D2 mengolah informasi pemahamannya terhadap permasalahan TPMG1 dengan pengetahuan yang sudah dikuasai yaitu konsep persegi, tetapi tidak mengingat konsep kubus subjek D2 menyimpan informasi dengan melakukan pengulangan informasi berupa konsep segitiga siku-siku dan rumus Pythagoras untuk menyusun rencana penyelesaian.

Paparan Data dan Hasil Wawancara D2 pada Tahap Melaksanakan Rencana Penyelesaian TPMG1 berikut:

Kutipan wawancara terhadap subjek D2 dengan peneliti dalam melaksanakan rencana penyelesaian TPMG1 sebagai

$\begin{array}{ll}\text { P-27 } & \text { : Bagaimana anda merencanakan penyelesaian dari masalah tersebut? } \\ \text { D2G1-27 } & \text { : Pertama membaca soal, terus memahaminya untuk membuat rencana menyelesaiannya. } \\ \text { P-31 } & \text { : Apakah anda dapat menunjukkan langkah-langkah penyelesaian masalah tersebut, sesuai yang anda rencanakan } \\ & \text { tadi? } \\ \text { D2G1-31 } & \text { Yang pertamakan menemukan jarak dari burung merpati ke tempat makan 1, tempat merpati tadi kan dimisalkan } \\ & \text { c dan tempat makanan 1 dimisalkan a. Kemudian jarak dari burung merpati ke tempat makan } 2 \text { yang tempat } \\ & \text { makanan 2 dimisalkan b, jadi terbentuk segitiga siku-siku seperti ini pada gambar 8). Terus menghitung jaraknya } \\ & \text { tersebut dengan menggunakan rumus Pythagoras. Dari kedua jarak tersebut dicari yang paling pendek yang mana. }\end{array}$

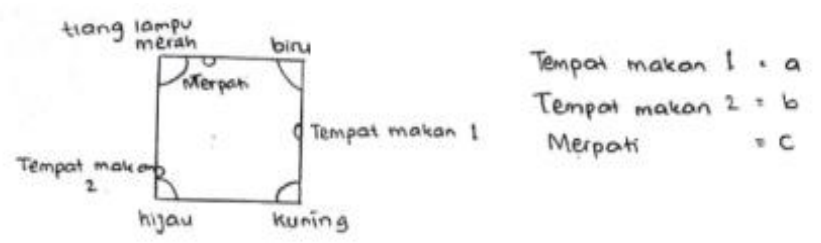

*

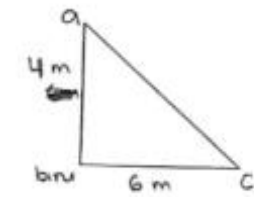

Jacak merpoti he tempat makan $1:$
$\begin{aligned} a c & =\sqrt{6^{2}+4^{2}} \\ & =\sqrt{36+16} \\ & =\sqrt{52} \mathrm{~m}\end{aligned}$

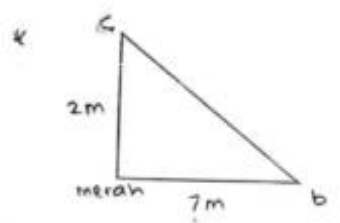

Jarak merpat ke tempat maken?

$\mathrm{Cb}=\sqrt{7^{2}+2^{2}}$

, $\sqrt{49+4}$

$=\sqrt{53} \mathrm{~m}$

\section{Gambar 9. Subjek D2 dalam Melaksanaan Rencana Penyelesaian TPMG1}

Berdasarkan kutipan wawancara tersebut diperoleh data subjek D2 mengingat rencana penyelesaian dan melaksanakan rencana penyelesaiannya sesuai dengan rencana yang dibuat), mengingat rumus Pythagoras ((D2G1-27, gambar 9 dan D2G1-31). Subjek D2 beragumen tidak logis dalam menggambar bangun dan tidak logis dalam menentukan jarak burung merpati dengan tempat makanan menggunakan rumus Pythagoras (D2G1-31 dan gambar 9). 


\section{Paparan Data dan Hasil Wawancara D2 pada tahap Melaksanakan Rencana Penyelesaian TPMG2} berikut:

Kutipan wawancara terhadap subjek D2 dengan peneliti dalam melaksanakan rencana penyelesaian TPMG2 sebagai

P-27
D2G2-27
P-29

D2G2-29
P-30
D2G2-30
P-31
D2G2-31
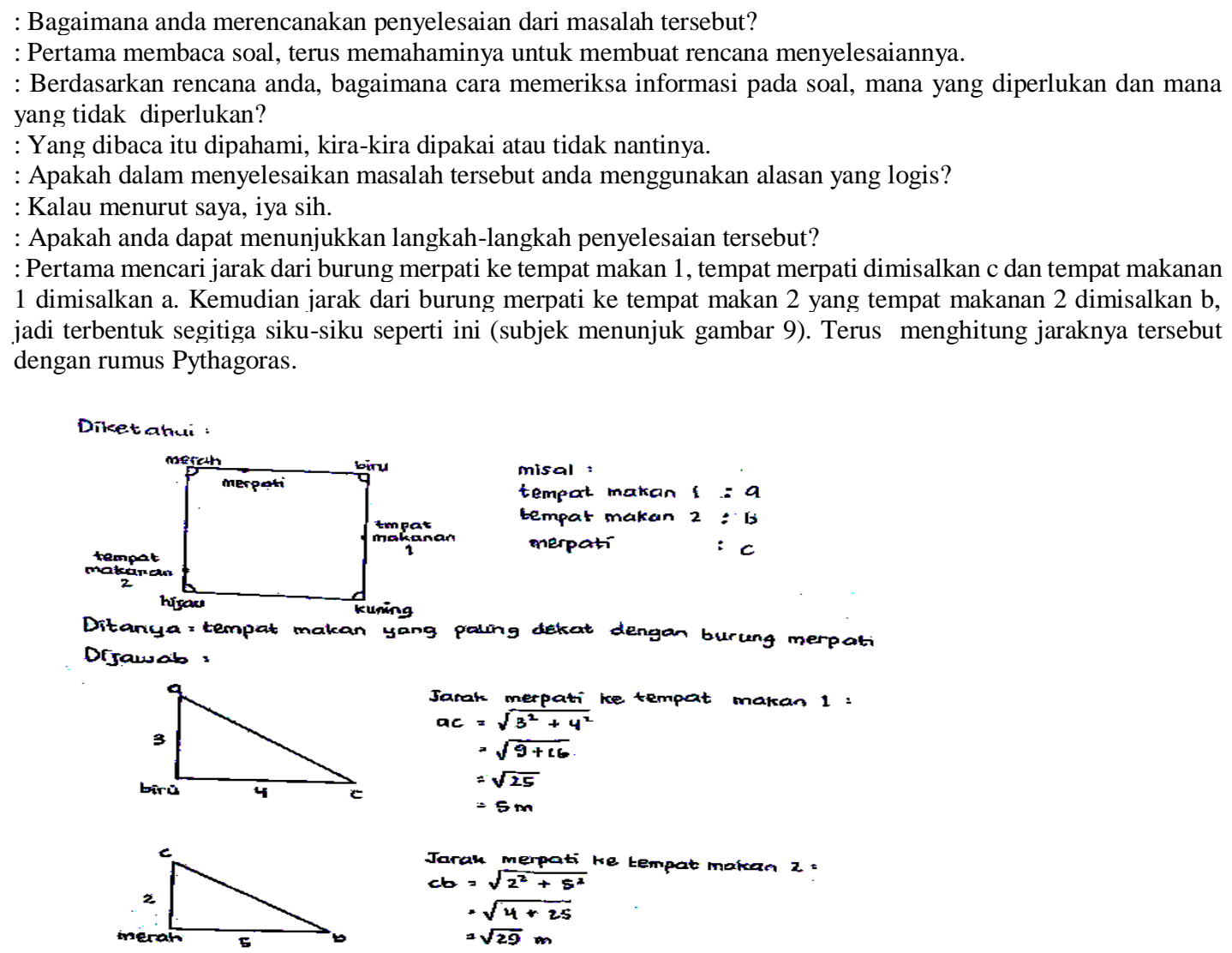

\section{Gambar 10. Subjek D2 dalam melaksanaan rencana penyelesaian TPMG2}

Menurut kutipan wawancara tersebut diperoleh data subjek D2 mengingat rencana penyelesaian dan melaksanakan rencana penyelesaiannya sesuai dengan rencana yang dibuat, mengingat rumus Pythagoras (gambar 10, D2G2-27 dan D2G2-31). Subjek D2 beragumen tidak logis dalam menggambar bangun dan beragumen tidak logis dalam menentukan jarak burung merpati dengan makanan d (D2G2-31 dan gambar 10).

Berdasarkan perbandingan data dari hasil wawancara subjek D2 dalam melaksanakan rencana penyelesaian TPMG1 dan TPMG2, terlihat bahwa kedua data merupakan data yang konsisten. Sehingga data yang diperoleh pada wawancara TPMG1 adalah valid. Dari hasil validasi data maka dapat dianalisa aktivitas mental subjek D2 pada tahap melaksanakan rencana penyelesaian. Yaitu subjek D2 memanggil kembali informasi berupa rencana penyelesaian menentukan jarak burung merpati dengan makanan. Dan mengingat rumus Pythagoras yang akan digunakan untuk menyelesaikan masalah. Subjek D2 mengolah informasi dengan mengaitkan rencana penyelesaian, informasi dari soal dan pengetahuan yang dikuasai. Subjek D2 tidak berargumen logis dalam menggambar bangun dan menentukan jarak burung merpati dengan tempat makanan. Subjek D2 menyimpan informasi dengan melakukan pengulangan langkah-langkah merencanakan penyelesaian.

\section{Paparan Data dan Hasil Wawancara D2 pada tahap Memeriksa Kembali TPMG1} berikut:

Kutipan wawancara terhadap subjek D2 dengan peneliti dalam memeriksa kembali penyelesaian TPMG1 sebagai 


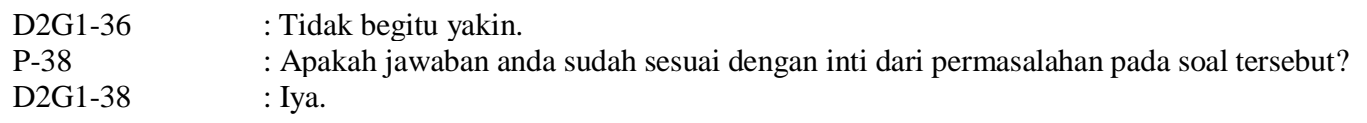

Berdasarkan kutipan wawancara tersebut diperoleh data subjek D2 memeriksa kembali jawabannya dengan cara mengoreksi ulang jawabannya (D2G1-35). Subjek D2 tidak yakin dengan hasil pekerjaannya (D2G1-36). Subjek D2 mengaitkan hasil penyelesaiannya dengan inti dari permasalahan pada soal (D2G1-38).

\section{Paparan Data dan Hasil Wawancara D2 pada tahap Memeriksa Kembali TPMG2}

Kutipan wawancara terhadap subjek D2 dengan peneliti dalam memeriksa kembali penyelesaian TPMG2 sebagai berikut:

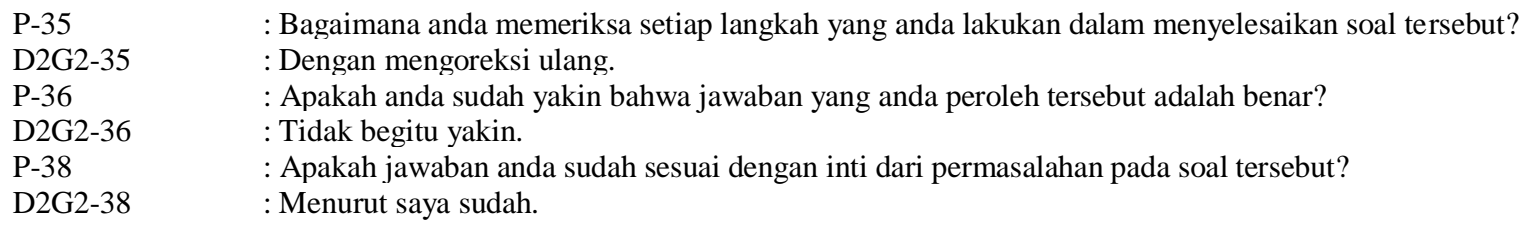

Menurut kutipan wawancara tersebut diperoleh data subjek D2 memeriksa kembali jawabannya dengan cara mengoreksi ulang (D2G2-35).S ubjek D2 tidak yakin dengan hasil pekerjaannya (D2G2-36). Subjek D2 mengaitkan hasil penyelesaiannya dengan inti dari permasalahan pada soal (D2G2-38).

Berdasarkan perbandingan data dari hasil wawancara subjek D2 dalam memeriksa kembali TPMG1 dan TPMG2, terlihat bahwa kedua data merupakan data yang konsisten. Sehingga data yang diperoleh pada wawancara TPMG1 adalah valid. Dari hasil validasi data maka dapat dianalisa aktivitas mental subjek D2 pada tahap memeriksa kembali. Yaitu subjek D2 memanggil kembali informasi dengan mengingat rencana penyelesaian dan melaksanakan rencana penyelesaian yang sudah dilakukan. Subjek D2 mengingat inti permasalahan dan mengingat pengetahuan yang dikuasai untuk melakukan pemeriksaan. Subjek D2 mengolah informasi yaitu mengaitkan kembali inti dari permasalahan dengan hasil penyelesaian yang telah dilakukan. Subjek D2 tidak yakin dengan hasil pekerjaannya setelah melakukan pemeriksaaan.

\section{PEMBAHASAN}

Pada tahap memahami masalah, subjek FD menerima informasi dengan membaca soal sebanyak tiga sampai empat kali. Penafsiran (persepsi) subjek terhadap informasi baru dari soal dengan menggambar bangun dahulu untuk mempermudah memahami masalah. Dalam mengolah informasi subjek FD mengaitkan informasi baru dari soal dengan pengetahuan yang dikuasai berupa konsep persegi, segitiga dan rumus Pythagoras dan memanggil kembali informasi dengan mendeskripsikan kembali pemahamannya terhadap permasalahan dengan menggunakan bahasa sendiri.

Subjek FD dalam menyimpan informasi dengan melakukan pengulangan informasi untuk memahami masalah berupa menggambar bangun yang terbentuk yang terkait dengan permasalahan berupa persegi. Pada tahap ini subjek FD tidak memahami masalah secara utuh saat memproses informasi dari soal karena gambar bangun yang terbentuk tidak sesuai dengan masalah yang diberikan. Hal ini selaras dengan hasil penelitian (Susanto, 2008) menunjukkan bahwa subjek FD dalam memahami masalah konsep grup tidak dapat merinci apa yang ada di dalam soal, meskipun subjek mampu menyelesaikannya. Demikian juga pendapat (Witkin et al., 1977) bahwa individu FD berpikir secara global dan mengalami kesulitan dalam membedakan stimulus melalui situasi yang dimiliki sehingga persepsinya mudah dipengaruhi oleh manipulasi dari situasi sekelilingnya. Sejalan dengan (Altun \& Cakan, 2006) yang menyatakan bahwa individu dengan gaya kognitif FD mengalami kesulitan dalam memisahkan stimulus dari situasi yang dimiliki. Sedangkan hasil penelitian (Ngilawajan, 2013) menunjukkan bahwa subjek FD sulit dalam memahami masalah turunan.

Pada tahap merencanakan penyelesaian, subjek FD memanggil kembali informasi dengan mengingat konsep segitiga dan rumus Pythagoras(merupakan pemahaman terhadap pengetahuan sebelumnya). Subjek FD menyimpan informasi dengan pengulangan konsep segitiga dan rumus Pythagoras untuk menyusun rencana penyelesaian. Senada dengan pendapat (Winkel, 2007) menyatakan bahwa pengkodean informasi (encoding) digunakan untuk menghubungkan dan mengintegrasikan informasi baru dengn yang lama agar tertahan di short term memory(STM). Saat merencanakan penyelesaian jarak antara burung merpati dengan tempat makanan, subjek FD tidak mengingat konsep kubus. Senada dengan (Amamah et al., 2016) bahwa subjek FD tidak mengingat atau mengalami forgotten lost terhadap konsep perbandingan. Dalam mengolah informasi rencana subjek FD untuk menghitung jarak antara burung merpati dengan temapat makanan adalah tidak logis. Kondisi ini berarti long term memory (LTM) subjek FD kurang baik dalam merekam pengetahuan dan pengalaman untuk menyelesaikan masalah geometri. Selaras (Panjaitan, 2013), mengatakan bahwa subjek dengan gaya kognitif FD sulit menata kembali informasi baru dan susah menghubungkan dengan pengetahuan yang lalu. 
Pada tahap melaksanakan penyelesaian, subjek FD memanggil kembali informasi berupa rencana penyelesaian menentukan jarak burung merpati dengan tempat makanan. Subjek FD menggunakan rumus Pythagoras untuk menyelesaikan masalah. Subjek FD mengolah informasi dengan mengaitkan rencana penyelesaian, informasi dari soal, dan pengetahuan yang dikuasai (berupa konsep segitiga dan rumus Pythagoras). Subjek FD tidak logis dalam menghitung jarak burung merpati dengan tempat makanan, karena konsep yang digunakan adalah persegi bukan konsep kubus. Ini menunjukkan bahwa subjek FD terpengaruh dengan situasi yang ada di soal(yaitu taman berbentuk persegi). Hal ini sesuai pendapat (Witkin et al., 1977) yang mengatakan subjek FD terpengaruh latar dan menerima permasalahan sebagai suatu keseluruhan (global) sehingga persepsinya mudah dipengaruhi oleh manipulasi dari situasi sekelilingnya.

Pada tahap memeriksa kembali penyelesaian, subjek FD memanggil kembali informasi dengan mengingat penyelesaian yang dilakukan, mengingat inti permasalahan. Subjek FD mengingat pengetahuan yang dikuasai (konsep segitiga dan rumus Pythagoras). Subjek FD merasa tidak yakin dengan jawabannya setelah melakukan pemeriksaan kembali. Subjek FD mengingat bangun datar tetapi tidak mengingat konsep bangun ruang (kubus). Sehingga subjek FD tidak menyadari adanya kesalahan dalam menentukan jarak burung merpati dengan tempat makanan. Subjek FD memeriksa kembali penyelesaiannya dengan melihat gambar dan memeriksa perhitungannya. Ini menunjukkan subjek FD kurang teliti dan kurang cermat dalam memeriksa kembali jawabannya. Penelitian (Gunawan, 2014) menunjukkan hasil yang serupa, yaitu pada tahap memeriksa kembali subjek FD tidak analitis dan tidak terstruktur dalam memeriksa kembali penyelesaian.

\section{SIMPULAN}

Pada tahap memahami masalah subjek FD tidak memahami masalah secara utuh saat memproses informasi dari soal karena gambar bangun yang terbentuk tidak sesuai dengan masalah yang diberikan. Pada tahap merencanakan penyelesaian, long term memori (LTM) subjek dengan gaya kognitif FD kurang merekam dengan baik pengetahuan dan pengalaman yang digunakan dalam menyelesaikan masalah geometri. Pada tahap melaksanakan penyelesaian, subjek FD tidak logis dalam menghitung jarak burung merpati dengan tempat makanan karena terpengaruh dengan situasi yang ada di soal (yaitu taman berbentuk persegi). Pada tahap memeriksa kembali, subjek FD kurang teliti dan kurang cermat dalam memeriksa kembali jawabannya.

Berdasarkan kesimpulan pada penelitian ini, hasilnya dapat digunakan sebagai informasi awal membuat penelitian yang lebih mendalam lagi dengan masalah yang sama tetapi tinjauannya yang berbeda. Misalnya analisis kesalahan, representasi, miskonsepsi pemahaman siswa terhadap konsep jarak pada bangun ruang. Untuk guru pengajar matematika dapat memperhatikan temuan tersebut sebagai bahan masukan dalam menyusun pembelajaran yang mengakomodasi perbedaan gaya kognitif siswa di kelas.

\section{DAFTAR RUJUKAN}

Abdussakir. (2009). Pembelajaran Geometri Sesuai Teori Van Hiele. Madrasah, 2(1). https://doi.org/10.18860/jt.v2i1.1832 Ahmadzade, L., \& Shojae, M. (2013). Investigating the Relationship between Cognitive Style (Filed Dependence/Independence) and Academic Achievement in Male and Female Students of Behbahan Islamic Azad University. Journal of Life Science and Biomedicine, 3(3), 245-249.

Altun, A., \& Cakan, M. (2006). Undergraduate Students' Academic Achievement, Field Dependent/Independent Cognitive Styles and Attitude Toward Computers. Educational Technology and Society, 9(1), 289-297.

Amamah, S., Sa 'dijah, C., \& Sudirman. (2016). Proses Berpikir Siswa SMP Bergaya Kognitif Field Dependent Dalam Menyelesaikan Masalah Berdasarkan Teori Pemrosesan Informasi. Jurnal Pendidikan: Teori, Penelitian, dan Pengembangan, 1(2), 237-245.

Ardana, I. M. (2007). Pengembangan Model Pembelajaran Matematika Berwawasan Konstruktivis yang Berorientasi pada Gaya Kognitif dan Budaya Siswa. Tesis tidak diterbitkan. Universitas Negeri Surabaya, Surabaya.

Guisande, M. A., Páramo, M. F., Tinajero, C., \& Almeida, L. S. (2007). Field Dependence-Independence (FDI) Cognitive Style: An Analysis of Attentional Functioning. Journal Psicothema, 19(4), 572-577.

Gunawan, I. I. (2014). Proses Berpikir Siswa SMP Dalam Menyelesaikan Masalah Geometri Berdasarkan Langkah Polya Ditinjau Dari Gaya Kognitif FD dan FI. Tesis tidak diterbitkan. Universitas Negeri Surabaya, Surabaya.

Husnaeni. (2001). Membangun Konsep Segitiga melalui Penerapan Teori Van Hiele pada Siswa Kelas IV Sekolah Dasar. Tesis tidak diterbitkan. Uniersitas Negeri Malang, Malang.

Jagom, Y. O. (2015). Kreativitas Siswa SMP Dalam Menyelesaikan Masalah Geometri Berdasarkan Gaya Belajar VisualSpatial dan Auditory-Sequential. Jurnal Pendidikan Matematika, 1(3), 176-190.

Kadir, P. (2010). Penerapan Pembelajaran Kontekstual Berbasis Potensi Pesisir sebagai Upaya Peningkatan Kemampuan Pemecahan Masalah, Komunikasi Matematik, dan Keterampilan Sosial Siswa SMP. Disertasi tidak diterbitkan. Universitas Pendidikan Indonesia, Bandung.

Kartono. (2010). Hands on Activity pada Pembelajaran Geometri Sekolah sebagai Asesmen Kinerja Siswa. Hands on Activity, 21-32. 
Kozhevnikov, M. (2007). Cognitive Styles in the Context of Modern Psychology: Toward an Integrated Framework of Cognitive Style. Journal of Psychological Bulletin, 133(3), 464-481. https://doi.org/10.1037/0033-2909.133.3.464

Krulik, S., \& Rudnick, J. A. (1988). Problem Solving: A Handbookfor Elementary School Teachers. Massachusetts: Allyn and Bacon, Inc.

Kutluca, T. (2013). The Effect of Geometry Instruction with Dynamic Geometry Software; GeoGebra on Van Hiele Geometry Understanding Levels of Students. Educational Research and Reviews, 8(17), 1509-1518. https://doi.org/10.5897/ERR2013.1554

Ma, H. L., Lee, D. C., Lin, S. H., \& Wu, D. B. (2015). A Study of Van Hiele of Geometric Thinking Among $1^{\text {st }}$ through $6^{\text {th }}$ Graders. Eurasia Journal of Mathematics, Science and Technology Education, 11(5), 1181-1196. https://doi.org/10.12973/eurasia.2015.1412a

Munandir. (2001). Ensiklopedia Pendidikan. Malang: UM Press.

Muniri. (2005). Pembelajaran Berdasarkan Tahap Berpikir Van Hiele untuk Membantu Siswa Membangun Pemahaman pada Materi Tiga Dimensi di Kelas I SMU Diponegoro Tulungagung. Tesis tidak diterbitkan. Universitas Negeri Malang, Malang.

NCTM. (2000). Principles and Standards for School Mathematics. Reston: The National Council of Teachers of Mathematics, Inc.

Ngilawajan, D. A. (2013). Proses Berpikir Siswa SMA dalam Memecahkan Masalah Matematika Materi Turunan Ditinjau dari Gaya Kognitif Field Independent dan Field Dependent. Pedogiga, 2(1), 71-83.

Panjaitan, B. (2013). Proses Kognitif Siswa Dalam Pemecahan Masalah Matematika. Jurnal Ilmu Pendidikan, 19(1), 17-25.

Purnomo, D. (1999). Penguasaan Konsep Geometri Dalam Hubungannya dengan Teori Perkembangan Berpikir Van Hiele pada Siswa Kelas II SLTP Negeri 6 Kodya Malang. Tesis tidak diterbitkan. Universitas Negeri Malang, Malang.

Rahman, A. (2010). Pengajuan Masalah Matematika Ditinjau dari Gaya Kognitif dan Kategori Informasi. Jurnal Ilmu Pendidikan, 19(2), 244-251.

Sa'dijah, C. (2008). Kemampuan Pemecahan Masalah Geometri Siswa SMP mnggunakan Pembelajaran Matematika Bersetting Kooperatif. Prosiding Konferensi Nasional Matematiba XIV, 739, 739-751.

Santrock, J. W. (2004). Psikologi Pendidikan. Jakarta: Kencana-Prenada Media Group.

Siswono, T. Y. E. (2008). Model Pembelajaran Matematika Berbasis Pengajuan dan Pemecahan Masalah untuk Meningkatkan Kemampuan Berpikir Kreatif. Surabaya: Unesa University Press.

Siswono, T. Y. E. (2016). Berpikir Kritis dan Berpikir Kreatif sebagai Fokus Pembelajaran Matematika. Seminar Nasional Matematika dan Pendidikan Matematika, 11-26.

Spagnolo, F., \& Di Paola, B. (2010). European and Chinese Cognitive Styles and Their Impact on Teaching Mathematics. Journal of Mathematics Educations, 3(2), 139-153. https://doi.org/10.1007/978-3-642-11680-3_1

Sudarman. (2011). Proses Berpikir Siswa Quitter pada Sekolah Menengah Pertama Dalam Menyelesaikan Masalah Matematika. Jurnal Edumatica, 01(2), 15-24.

Sugiyono. (2005). Memahami Penelitian Kualitatif. Bandung: Alfabeta.

Susanto, H. A. (2008). Mahasiswa Field Independent dan Field Dependent Dalam Memahami Konsep Grup. Seminar Nasional Matematika dan Pendidikan Matematika, 64-77.

Suwito, A., Yuwono, I., Parta, I. N., \& Irawati, S. (2017). Geometry High School Students Thinking Ability Based On level van Hiele. International Conference on Mathematics: Education, Theory, and Application (ICMETA): Volume 1/2017, June 27th 2017, 200-207.

Takker, S., \& Subramaniam, K. (2012). Understanding Teachers’ Knowledge of and Responses to Students’ Mathematical Thinking. International Congress on Mathematical Education, (24), 4906-4915.

Tristanti, F., Sa'dijah, C., \& Gipayana, M. (2017). Kemampuan Pemecahan Masalah Matematika Pada Materi Kubus dan Balok Bagi Siswa Kelas V Sekolah Dasar. Prosiding TEP \& PDs: Transformasi Pendidikan Abad 21, (7), $230-239$.

Witkin, H. A., Moore, C. A., Goodenough, D., \& Cox, P. W. (1977). Field-Dependent and Field-Independent Cognitive Styles and Their Educational Implications. Review of Educational Research, 47(1), 1-64. https://doi.org/10.3102/00346543047001001

Wu, D., \& Ma, H. (2006). The Distributions of Van Hiele Levels of Geometric Thinking Among $1^{\text {st }}$ through $6^{\text {th }}$ Graders. International Group for the Psychology of Mathematics Education, 5, 409-416.

Wu, M., \& Adams, R. (2006). Modelling Mathematics Problem Solving Item Responses Using a Multidimensional IRT Model. Mathematics Education Research Journal, 18(2), 93-113.

Yazdani, M. A. (2007). Correlation Between Students' Level of Understanding Geometry According to the van Hieles' Model and Students' Achievement in Plane Geometry. Journal of Mathematical Sciences \& Mathematics Education, 2(2), 4045 . 